\title{
ON-LINE RETAILING: AN INVESTIGATION INTO THE SUCCESS FACTORS
}

\author{
WILLIAM GOLDEN, MARTIN HUGHES and PATRICIA GALLAGHER \\ Department of Accountancy and Finance, National University of Ireland
}

\begin{abstract}
This research is a descriptive study to identify some of the factors that contribute to the successful use of e-business. The research was focused on the retail Industry in Ireland, and more specifically on existing on-line retailers of Irish made gifts. The study was conducted using a postal survey. The research found that specific organisational factors - early adoption of web technology, internal IS/IT expertise, having an e-business strategy, and a person who champions the e-business project - does result in more successful e-business presences. Further, the research found no evidence to support the belief that certain product types are more likely to be successful on the web.
\end{abstract}

\section{INTRODUCTION}

Electronic commerce is said to overcome barriers to trading internationally hence making companies truly global without the need for a physical presence in another country. With over 90 million people worldwide claiming Irish descent, they represent a potential lucrative export market that can be reached cost effectively by leveraging the capabilities of electronic commerce.

The Crafts Council of Ireland (www.ccoi.ie) estimates that $66 \%$ of the crafts industry is located in rural areas. Therefore the Internet presents a great opportunity for these companies to overcome location disadvantages. While the retail market in Ireland is said to be worth in excess of IR£20 billion a year, the Crafts Council estimates that the gross turnover of the crafts industry is $£ 92$ million per annum.

The original version of this chapter was revised: The copyright line was incorrect. This has been corrected. The Erratum to this chapter is available at DOI: 10.1007/978-0-387-35692-1_36 
This paper presents a descriptive study conducted with the aim of determining some of the factors that contribute to the success of retailers using electronic commerce to perform effectively in export markets. The focus of this research is on Irish export retailers in the crafts sector.

\section{LITERATURE REVIEW}

Electronic commerce has the potential to revolutionise the retail industry. Like other revolutions, some firms will be more adept at riding the new wave than others. The key factors that will enable organisations to be more successful in their adoption of web based e-commerce are twofold organisational factors and industry specific factors.

\subsection{Organisational factors influencing web site success}

"The first man gets the oyster; the second man gets the shell." (Andrew Carnegie).

Some commentators believe that many of the successful companies on the web owe their success merely to the fact that they were first to exploit the capabilities of the Internet as a channel for business (Enders \& Jelassi, (2000), Mellahi \& Johnson, (2000)). While De Figueiredo (2000) points out that first movers will have some advantage and early movers have the highest website stickiness.

However, Golder \& Tellis's (1993) study of first mover firms found that first movers did not enjoy exceptional and sustained benefits. Kerin et al. (1992) also support the view that being first to market does not automatically ensure dominant market share or long-term rewards.

Bhatnagar, Misra, \& Rao (2000) state that the companies who are successful on the Internet have previous technological experience. Companies that have staff with IT skills and an IT department in their business will be more successful when operating online (Bhatnagar, Misra, \& Rao, 2000). Mellahi \& Johnson (2000) conclude after conducting a case study on Amazon.com, that the critical resources in the electronic commerce industry that result in competitive advantage are largely intangible assets and capabilities, such as innovation, technical expertise and knowledge. Thus, the technological experience and knowledge that companies have are critical factors in determining success in electronic commerce (Savin \& Silberg, 2000).

Venkatraman (2000) comments that a business strategy that fails to recognise the Internet is destined to fail. A recent KPMG survey shows that 
mangers are aware of the need to execute a web strategy to complement existing business models (Venkatraman, 2000). They point out that it is critical for traditional retailers to begin to clearly define their web strategy.

Griffith \& Krampf (1998) indicate areas which managers can build an ebusiness strategy on: online sales which are consistent with the definition of retailing; communication which involves advertising, promotion and building corporate brand image; and customer service where the Internet provides a rare opportunity for retailers to provide exceptional customer service by being both accessible and responsive.

Venkatraman (2000) points out that every company will need to develop a strategy for the dot-com world and ultimately, business strategy will be dot-com strategy. Vision, governance, resources, and alignment are the stepping-stones to a successful web strategy (Griffith \& Palmer, (1999), Venkatraman, (2000), Hackbarth \& Kettinger, (2000)).

Many organisations lack a central decision maker for e-business and need someone to oversee all aspects of e-commerce including e-commerce strategy development and implementation (Schuette, 2000). Barry (2000) and Bergstein (2000) found that companies who have a web champion to run, maintain, and update their web site have a higher number of hits and repeat visits than web sites that do not have an appointed web champion. An individual with responsibility for the web project is an important factor in successful e-businesses (Chen \& Leteney, (2000), De Figueiredo, (2000)).

The maintenance of a fully interactive web site involves thorough background planning. Competitors who spend time and effort designing well thought out web presences will most likely gain from the mistakes made by businesses that proceed without planning (Van Doren et al., 2000). Indeed, the difference between success and failure on the web often hinges on how carefully people sift through details and fine-tune trivial plans (Brown et al, 1999). A case study conducted by Chan and Swatman (2000) revealed Internet based e-commerce requires the same amount of planning and foresight as any previous form of e-commerce, even though it may appear simpler. In another study Spiller \& Lohse (1997) investigated the effects of effective customer interfaces on traffic and sales in online stores. They posit that the promise of electronic commerce, and online shopping in particular, will depend to a large extent upon the interface and how people interact with the computer.

\subsection{Retail specific factors influencing web site success}

Kiang et al. (2000) contend that product characteristics play a major role in the successful marketing of a product on the Internet. Phau \& Poon (2000) state that one weakness of the Internet is that it can realistically reproduce 
only two of our five senses - sight and sound. Therefore this limitation will restrict the types of products that are saleable on the Internet. Peterson et al. (1997) classified products and services for sale on the Internet versus a retail store along three dimensions: cost and frequency of purchase; value proposition; degree of differentiation. In general, when purchase fulfilment requires physical delivery, the more frequent the purchase and the smaller the cost, it is less likely that there is a good 'fit' between a product and Internet based marketing. Along the second dimension, Internet related marketing is particularly well suited to certain types of intangible or service related goods (i.e. those based on digital assets). The third dimension reflects the degree to which a product or service is differentiable. When products are capable of significant differentiation, the Internet can serve as an effective segmentation mechanism for guiding buyers to their ideal product (Peterson et al., 1997).

Enders \& Jelassi (2000) further this point to say that any products that can be delivered in a digital format are likely to experience a radical shift towards online retailing because the customer has no substantial reason to visit a physical store. The Economist Shopping Survey (26th February, 2000) shows the simplest distinction is between 'high touch' and 'low touch' goods. High touch items are goods that consumers would prefer to see and touch before they purchase whereas low touch items are more standard items such as books, CDs, and computers.

Merchandise represents the full range of products the retailer offers to potential customers. The merchandise a retailer holds defines the store for the customer (Reardon \& Hasty, (1997), Berman \& Evans, (1994), Lindquist, (1975), Chen \& Leteney, (2000)). Christensen \& Tedlow (2000) point out that in categories ranging from books to chemicals, web stores can offer a selection that no bricks and mortar store can match. Customers prefer a store with a large selection (Spiller \& Lohse, (1997), Ng, Pan, \& Wilson, (1998), Enders \& Jelassi, (2000), Walsh \& Godfrey, (2000)). Spiller \& Lohse (1997) found that many retailers do not take advantage of adding rich product descriptions with many just transferring paper catalogues directly onto the web.

David Pottruck, president of Charles Schwab \& Co., first used the phrase 'Clicks \& Mortar' as he described the company's efforts to coordinate all its services. Pottruck predicted that future business success would not hinge on a battle between bricks and mortar companies against online efforts, but in successfully integrating the two - "the marriage of the best of the physical world and the best of technology". Chen \& Leteney (2000) point out that Internet retailers are being forced to recognise the importance of having a physical presence. De Figueiredo (2000) further stresses this by arguing that 
if traditional companies do not establish effective electronic commerce ventures to compete with their own core businesses, others will. Selling through existing physical stores and through Internet channels allows retailers to leverage the strengths of each channel with stores and websites working well together thus increasing sales at both (Chen \& Leteney, (2000), Quinn, (1999), Gulati \& Garino, (2000), Enders \& Jelassi, (2000), The Economist, (26th February 2000)). Gulati \& Garino (2000) point out the benefits that integration offers such as cross promotion, shared information, purchasing leverage, and distribution economies. Despite all these advantages, Enders \& Jelassi (2000) point out that as retailers move online, they also face challenges such as organisational restructuring and the adaptation of the existing distribution infrastructure to the new requirements of the online market. Conversely, many Internet retailers who have so far focused solely on the Internet aim to expand their access to new customers by moving into the physical front end of the value chain by adding physical retail stores (Enders \& Jelassi, 2000).

\section{RESEARCH METHODOLOGY}

This research is a descriptive study to identify some of the factors that contribute to Irish retailers using e-business successfully. In order to assess to what extent the on-line presences were successful three measures along the customer-purchasing model were chosen - Browsing, request for information and purchase. These measures were assessed as follows: (1) the number of hits per week to the website, (2) sales leads generated as a result of the website and (3) turnover generated directly from the website.

These success measures were used to test two proposed hypotheses:

H1: Organisational factors influence the success of the web site.

H1a: Early adopters are more successful

H1b: Organisations with higher levels of IS/IT expertise are more successful

Hlc: Organisations with an e-business strategy are more successful

H1d: Organisations who have a web champion are more successful

Hle: Organisations who engage in planning are more successful

H1f: Organisations who spend more on the development of their web site are more successful

$\mathrm{H} 2$ : Retail specific factors influence the success of the web site.

H2a: The characteristics of the products being sold influence the degree of success achieved 
$\mathrm{H} 2 \mathrm{~b}$ : Organisations with larger online product catalogues are more successful

$\mathrm{H} 2 \mathrm{c}$ : Organisations with an integrated "clicks and bricks" strategy are more successful.

The primary research was conducted by a postal survey. The sampling frame used was that of companies registered to any of fifteen Irish web directories under the categories 'gifts' or 'arts \& crafts'. Gifts are defined as items given as presents or articles suitable for presents. Arts and crafts are defined as products created using a particular skill and sold as gifts or products for personal use. The main areas of manufacturing in the Irish craft industry are pottery, glass, textiles (particularly knitwear), furniture, and quality giftware. Irish craft businesses are typically small in scale and are geographically widespread, but taken nationally the industry is a significant employer. Each website was visited to ensure that the company sells online.

The questionnaire was mailed to 280 companies along with a personally addressed covering letter to the relevant person in the company. Of the 280 questionnaires mailed, 122 were returned for a response rate of $43.5 \%$. Of these 122,44 were returned after a second mailing of the questionnaire was sent to companies who had not responded after two weeks.

Non-response bias was assessed by treating responses received after the deadline given (two weeks after the first mailing of the questionnaire) as being representative of non-respondents. Chi-Square significance tests were used to test for significant differences between the first respondents and the late respondents in the study. The early and late respondents did not differ significantly (at $p<.05$ ) on the measures of success (hits, revenues, and sales leads) and the other variables tested including e-business strategy, web champion, IS/IT expertise and product characteristics.

The results of the questionnaires were analysed using SPSS version 10.1. The responses were first analysed using statistical measures such as means, standard deviations and frequencies. For more advanced statistics, the Chisquare test for independent samples was used. The chosen level of confidence for the research was $\alpha=.05$.

\section{PROFILE OF ORGANISATIONS}

The majority of companies have been in business for more than 8 years $(58.5 \%)$, with only $4 \%$ of companies being in business for less than 1 year. The organisations surveyed are early adopters of e-business within their industry - only $17 \%$ believe that their competitors adopted e-business before 
them. In addition, the majority developed a website on their own initiative and not as the result of any outside pressure. Not only have these firms adopted e-business, but the majority $(81 \%)$ are also generating revenue directly through their web site.

The main reasons for getting involved in e-business were to acquire new customers (93\%), to gain international exposure (90\%), to advertise $(79 \%)$, to overcome the company's location disadvantage $(60 \%)$, to provide online customer support (59\%), to gain cost savings (41\%) and to gather customer information (31\%). As such, the main motivator for e-business adoption was as a sales mechanism rather than as a means to cut costs, or improve business processes.

The expectations of companies with respect to sales and competitiveness have been realised for the majority of the companies. $79 \%$ believe it has created new business, $68 \%$ believe it gives them a competitive edge, $62 \%$ have increased their sales in export markets. With respect to cost savings and business process improvements only $39 \%$ believe that e-business speeds up the delivery of their product and $35 \%$ believe that it has resulted in substantial cost saving.

The use of e-business is changing the industry structure within which these firms operate. Firstly, it is increasing competition within the industry (only $17 \%$ believe it is not), and secondly it is giving rise to disintermediation $-40 \%$ have cut out intermediaries in the sales process and ebusiness has allowed $84 \%$ of companies to sell directly to their final customers.

\subsection{Metrics of success}

$75 \%$ of firms are receiving between 1 and 500 hits to their website per week, (with 26\% receiving less than 50 hits per week, 26\% receiving between 101-500 hits per week and the remaining 23\% receiving between 50-100) (Figure 1). Of the $25 \%$ who received more than 500 hits per week, $8 \%$ receive more than 5,000 hits per week. 


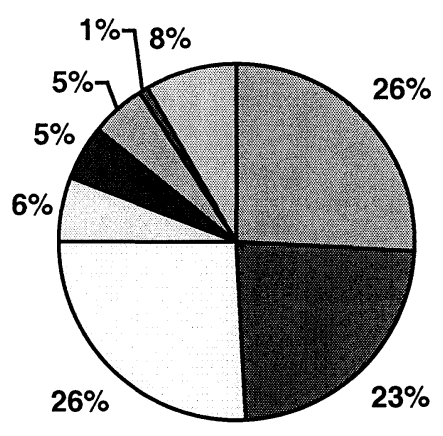

\begin{tabular}{|l|}
$\square$ Less than 50 \\
$\square 50-100$ \\
$\square 101-500$ \\
$\square 501-1000$ \\
$\square 1001-2000$ \\
$\square 2001-3000$ \\
$\square 3001-5000$ \\
$\square$ More than 5000 \\
\hline
\end{tabular}

Figure 1. Number of Hits per Week

Nearly half of the respondents (49\%) believe that $1-20 \%$ of sales leads are generated as a result of the website, while a further $12 \%$ consider that $21-40 \%$ of sales leads are generated as a result of the website (Table 1). Another $21 \%$ of companies believe that anywhere between $41 \%$ and $100 \%$ of sales leads are generated as a result of their Internet presence. However, $17 \%$ of respondents thought that none of their sales leads were generated through the website.

\begin{tabular}{|l|l|}
\hline$\%$ of Sales Leads Generated from Website & \% of Companies \\
\hline $0 \%$ & $17 \%$ \\
$1-20 \%$ & $49 \%$ \\
$21-40 \%$ & $12 \%$ \\
$41-60 \%$ & $6 \%$ \\
$61-80 \%$ & $3 \%$ \\
$81-100 \%$ & $6 \%$ \\
Don't Know & $7 \%$ \\
\hline
\end{tabular}

Table 1. \% of Sales Leads Generated from Website

The third measure of success is turnover generated by the website. A small percentage of firms (8\%) are generating between $81-100 \%$ of their 
revenue from the website (Figure 2). A further 9\% are generating between $21 \%$ and $80 \%$ of revenues from their website. However, most companies (64\%) are only generating between 1 and $20 \%$ of revenues from the website. Despite these promising figures, a further $20 \%$ of companies are generating no revenue at all from their website.

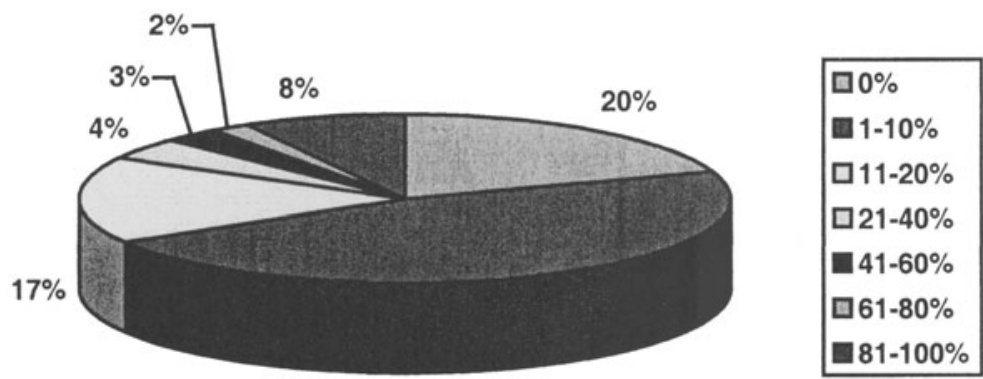

$46 \%$

Figure 2. \% of Annual Turnover Generated by Web site

\section{FINDINGS}

The study found that significant relationships do exist between some of the organisational factors hypothesised and the web site success measures. The extent and the nature of these relationships are presented in Tables 2 and 4.

\begin{tabular}{|l|l|l|l|l|l|l|}
\hline \multirow{2}{*}{$\begin{array}{l}\text { Organisational } \\
\text { Drivers of web } \\
\text { site success }\end{array}$} & \multicolumn{2}{|l|}{$\begin{array}{l}\text { Number of Hits per } \\
\text { week }\end{array}$} & \multicolumn{2}{l|}{$\begin{array}{l}\text { Number of Sales } \\
\text { leads generated }\end{array}$} & \multicolumn{2}{l|}{$\begin{array}{l}\text { Amount of revenue } \\
\text { generated }\end{array}$} \\
\cline { 2 - 7 } & $\begin{array}{l}\text { Chi } \\
\text { Square }\end{array}$ & $\begin{array}{l}\text { Cramer's } \\
\text { V }\end{array}$ & $\begin{array}{l}\text { Chi } \\
\text { Square }\end{array}$ & $\begin{array}{l}\text { Cramer } \\
\text { s V }\end{array}$ & $\begin{array}{l}\text { Chi } \\
\text { Square }\end{array}$ & $\begin{array}{l}\text { Cramer' } \\
\text { s V }\end{array}$ \\
\hline $\begin{array}{l}\text { 1st Mover } \\
\text { Advantage } \\
\text { Length of time } \\
\text { on Www } \\
\text { Exploit before } \\
\text { competitors } \\
\text { IS/IT }\end{array}$ & .005 & .005 & .005 & .005 & & \\
$\begin{array}{l}\text { Experience } \\
\text { Level of IS/IT }\end{array}$ & .003 & .011 & .006 & .006 & & \\
\hline
\end{tabular}




\begin{tabular}{|c|c|c|c|c|c|c|}
\hline $\begin{array}{l}\text { expertise } \\
\text { E-business } \\
\text { Strategy } \\
\text { Formal e- } \\
\text { business } \\
\text { strategy } \\
\text { Integrated e- } \\
\text { business } \\
\text { strategy } \\
\text { Champion } \\
\text { Leader of e- } \\
\text { business project } \\
\text { Planning of } \\
\text { Website } \\
\text { Security of } \\
\text { customer } \\
\text { information } \\
\text { Security of } \\
\text { payment } \\
\text { Ease of } \\
\text { Navigation } \\
\text { Ease of use of } \\
\text { checkout } \\
\text { Minimising } \\
\text { customer effort } \\
\text { in the purchase } \\
\text { process } \\
\text { Full Product } \\
\text { Catalogue } \\
\text { Uses customer } \\
\text { profiles to } \\
\text { anticipate future } \\
\text { needs } \\
\text { Development } \\
\text { Costs } \\
\text { Money spent } \\
\text { developing Web }\end{array}$ & $\begin{array}{l}.000 \\
.000 \\
.012\end{array}$ & $\begin{array}{l}.000 \\
.000 \\
.000 \\
.012\end{array}$ & $\begin{array}{l}.025 \\
.025\end{array}$ & $\begin{array}{l}.006 \\
.025 \\
.022\end{array}$ & .005 & .005 \\
\hline
\end{tabular}

Table 2. Organisational drivers of web site success

\subsection{Organisational drivers of web site success}

Two metrics were used to assess the extent to which firms were earlyadopters of web technology - years using the web, and extent to which they believe they were early adopters of the technology. Companies who adopted e-commerce early gain significantly more hits, and sales leads. However, these hits and sales leads do not turn into significantly more online revenue. 
The majority of the firms (55\%) believe that they exploited the capabilities of the Internet before their competitors. The early exploiters of the web gain significantly more hits and sales leads, however these are not converted into hard cash in terms of online sales. Early adopters are reaping rewards in terms of visitors to their site and subsequent sales enquiries but these are not being converted online.

The research examined whether there was a difference in how successful a company was depending on the level of IS/IT expertise in the company. $12 \%$ of the companies surveyed have an excellent level of IS/IT expertise in their organisation, 38\% have above average levels of IS/IT expertise. 32\% cited an average level of expertise with the remaining $13 \%$ and $5 \%$ falling into the below average and poor categories respectively. Those with better IS/IT expertise were significantly more successful in terms of hits and sales leads generated, but not in online sales.

The extent to which an e-business strategy had a positive outcome on success was assessed using two measures - the extent to which a formal ebusiness strategy existed and how well this e-strategy was integrated into the business strategy. $54 \%$ of firms have an e-business strategy in place while the remaining $46 \%$ do not have an e-business strategy. The results show a significant relationship exists between the existence of an e-business strategy and both the number of hits and the amount of sales leads generated. However, no statistical significance to on-line turnover was found.

$56 \%$ have integrated e-business and business strategies, while $17 \%$ do not have. Having integrated strategies results in significantly more hits and generates more sales leads, but not online revenue. Thus there is partial support for the idea that an e-business strategy leads to a more successful ebusiness.

$78 \%$ of companies have a person who leads the e-business project in their company. Having such a champion significantly improves the number of hits that a site generates, but does not bring significant benefits in the other two success measures - sales leads generated and online revenue.

The research investigated the extent to which firms engaged in planning prior to launching their web site. The majority of firms actively pre-planned their web presence. However, such planning only has a limited impact on the success of the website. Attending to the needs of customers in terms of securing their information and making it easy for them to use the shopping cart facilities improves the number of hits, but not the amount of revenue generated. 


\begin{tabular}{|l|l|l|l|l|l|}
\hline $\begin{array}{l}\text { When planning the design of } \\
\text { the website, the following } \\
\text { were considered important }\end{array}$ & $\begin{array}{l}\text { Strongly } \\
\text { Disagree }\end{array}$ & $\begin{array}{l}\text { Dis- } \\
\text { agree }\end{array}$ & Neutral & Agree & $\begin{array}{l}\text { Strongly } \\
\text { Agree }\end{array}$ \\
\hline $\begin{array}{l}\text { Security of customer } \\
\text { information }\end{array}$ & $3 \%$ & $6 \%$ & $24 \%$ & $27 \%$ & $41 \%$ \\
$\begin{array}{l}\text { Security of payment } \\
\text { Ease of navigation }\end{array}$ & $4 \%$ & $3 \%$ & $17 \%$ & $24 \%$ & $53 \%$ \\
$\begin{array}{l}\text { Site search facilities } \\
\text { Ease of use of checkout }\end{array}$ & $2 \%$ & $2 \%$ & $6 \%$ & $30 \%$ & $62 \%$ \\
facilities & $1 \%$ & $3 \%$ & $23 \%$ & $38 \%$ & $33 \%$ \\
$\begin{array}{l}\text { Minimising effort in the } \\
\text { purchase process }\end{array}$ & $3 \%$ & $17 \%$ & $27 \%$ & $51 \%$ \\
$\begin{array}{l}\text { Full online product catalogue } \\
\text { Interactive features }\end{array}$ & $1 \%$ & $7 \%$ & $17 \%$ & $40 \%$ & $35 \%$ \\
$\begin{array}{l}\text { Detailed company information } \\
\text { Projection of a favourable } \\
\text { corporate image }\end{array}$ & $6 \%$ & $27 \%$ & $24 \%$ & $4 \%$ & $4 \%$ \\
\hline
\end{tabular}

Table 3. Planning Issues undertaken during Web design

Making the site easy to navigate and minimising the effort to complete a purchase increases the number of sales leads, but again not revenues generated. The only planning element that does significantly improve the revenue generating capabilities of the site is deciding to put the full product catalogue of the company on-line from the beginning.

Some firms also continue the planning process once the web-site is live. $43 \%$ use the customer profiles generated from the website to anticipate future needs and requirements of customers. Those who engage in this activity are significantly more likely to generate increased sales leads from their e-business activity. As such, proactive management of customer information obtained via the web site can yield successful results in terms of providing a more customised and focused product offering.

$59 \%$ of companies spent between $£ 1-£ 5,000$ developing their website, a further $22 \%$ spent between $£ 5,001-£ 10,000$, while another $14 \%$ spent between $£ 10,001-£ 50,000$ and $5 \%$ spent more than $£ 50,000$ developing their website. The amount of money that a company spends on its web site is not significantly related to any of the measures of success.

\subsection{Retail specific drivers of web site success}

Part of this research sought to assess the extent to which certain traits unique to retail impacted on the success of a web site. In particular the significance of the products' characteristics, the number of products for sale and the extent of integration between bricks and clicks was assessed. 


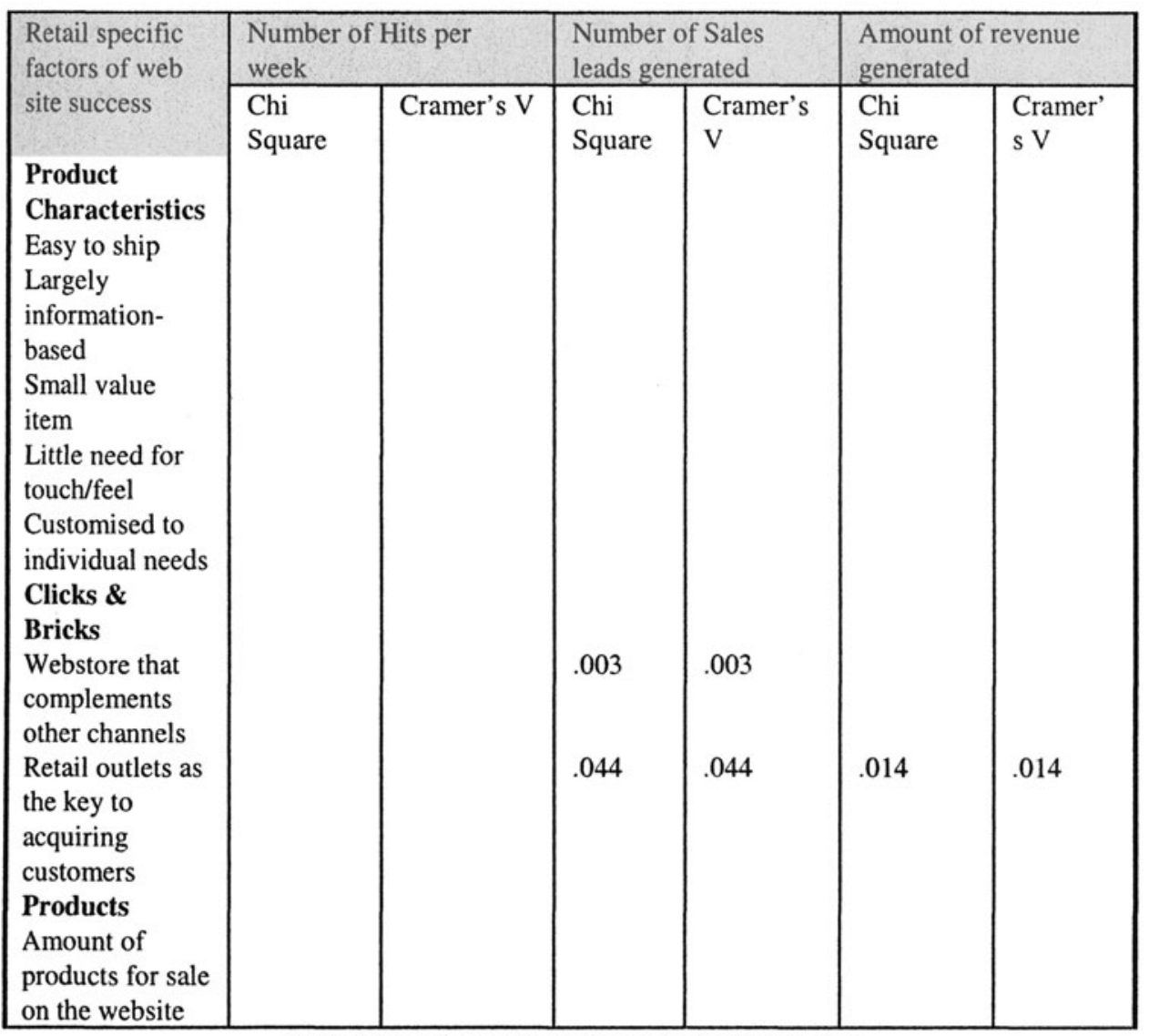

Table 4. Retail specific factors of web site success

The results show no statistical significance between any of the characteristics of the products being sold on-line and the measures of success. $65 \%$ of companies have a product that is easy to ship. However, this fact does not result in higher revenues, a higher number of hits or a higher number of sales leads. Also, even though the literature presents one of the main advantages of online selling as the ability to customise products, there is no significance between customisable products and any of the three success measures, despite the fact that $42.4 \%$ of companies sell products that are customisable to individual customer needs. The other characteristics small value item, little need for touch/feel and largely information based also had no significant impact on the success measures for on-line retailing. 


\begin{tabular}{|c|c|c|c|c|c|}
\hline Product Characteristics & $\begin{array}{l}\text { Strongly } \\
\text { Disagree }\end{array}$ & Disagree & Neutral & Agree & $\begin{array}{l}\text { Strongly } \\
\text { Agree }\end{array}$ \\
\hline Easy to ship & $5 \%$ & $5.9 \%$ & $23.5 \%$ & $34.5 \%$ & $31.1 \%$ \\
\hline Largely Information based & $34.5 \%$ & $25.2 \%$ & $27.7 \%$ & $10.1 \%$ & $2.5 \%$ \\
\hline Small Value Item & $16.8 \%$ & $21 \%$ & $28.6 \%$ & $21 \%$ & $12.6 \%$ \\
\hline $\begin{array}{l}\text { Little need for touch/feel to } \\
\text { evaluate product }\end{array}$ & $12.6 \%$ & $21.8 \%$ & $30.3 \%$ & $21.8 \%$ & $13.4 \%$ \\
\hline $\begin{array}{l}\text { Customised to individual } \\
\text { needs }\end{array}$ & $11.8 \%$ & $17.6 \%$ & $20.2 \%$ & $21.8 \%$ & $20.6 \%$ \\
\hline
\end{tabular}

Table 5. Characteristics of products being sold online

$21 \%$ of the companies surveyed had more than 100 products available on their website, with a further $21 \%$ offering between 50 and 100 products. The breadth of the product offering on a web site did not influence its success no significant relationship was found in respect of any of the measures of success.

The majority of the companies use multiple sales channels to sell their products with only $11.5 \%$ selling exclusively on the Internet. Other outlets used include retail outlets $(70 \%)$, mail order $(50 \%)$ and 3rd party sellers (27\%). The companies are export focused $-37 \%$ have exports that account for in excess of $40 \%$ of their annual turnover. The web site is seen as a complementary sales channel for the majority of companies (62\%). Those who use the web as a complementary sales channel gain significantly more sales leads from their e-business presence. At a more specific level, $43 \%$ of companies believe that retail outlets are the key to acquiring new customers ( $26 \%$ believe the are not). Companies who believe that they are presently dependent on retail outlets for new sales generate significantly more sales leads and on-line revenue from their web site.

\section{CONCLUSIONS AND FURTHER RESEARCH}

The presence of specific organisational factors - early adoption of web technology, internal IS/IT expertise, having an e-business strategy, and a person who champions the e-business project - results in more successful ebusiness presences. In particular the extent to which these organisational factors are present greatly improves the degree to which customers seek information from, and enquire about products on a retailer's web site. However, these same organisational factors do not significantly impact the amount of sales completed online. This however may be due to the fact that customers are using retail websites to gather information, but still prefer to 
complete the transaction in a physical store. Support for this interpretation is provided in that $75 \%$ of firms see their web site as a source of sales leads.

It is a commonly held belief that certain product types are more likely to be successful on the web - this study found no evidence to support this view point. In addition, the number of products on offer through the web site is not a good predictor of the likely success of the web site. The extent to which a retail company integrates its web presence with its physical presence is likely to produce significant success for the web site in terms of sales leads generated and online revenues.

This study was descriptive in nature and also limited in scope. Further research is required to further investigate the conclusions drawn in this research. In particular, there is a need to replicate the study using a wider, or alternative, population sample as this study was confined to Irish retail organisations that sell giftware on-line.

The web site success measures presented in this paper could be broadened and developed in future research. For example, other measures of success that could be incorporated into future studies include customer loyalty, customer satisfaction and cost reductions achieved.

\section{REFERENCES}

Anonymous (2000). Shopping around the Web - A Survey of E-commerce. The Economist. Barry, J. (2000). Avoid the pitfalls of going from bricks to clicks. Internetweek. 796: 19-20.

Bergstein, M. (2000). Digital Strategies - Look before you leap, Diamond technology partners.

Berman, B. and J. R. Evans (1994). Retail Management: A Strategic Approach, Prentice Hall.

Bhatnagar, A., S. Misra, et al. (2000). "Why some consumers are online shoppers while others are not." Communications of the ACM 43(11): 98-106.

Chan, C. and P. M. C. Swatman (2000). "From EDI to Internet commerce: the BHP Steel experience." Internet Research-Electronic Networking Applications and Policy 10(1): 72 82.

Chen, S. and F. Leteney (2000). "Get Real! Managing the Next stage of Internet Retail." European Management Journal 18(5): 519-528.

Christensen, C. M. and R. S. Tedlow (2000). "Patterns of Disruption in Retailing." Harvard Business Review 78(1): 42-48.

De Figueiredo, J. M. (2000). "Finding Sustainable Profitability in E-commerce." Sloan Management review Summer 2000: 41-52.

Enders, A. and T. Jelassi (2000). "The Converging Business models of Internet and Bricks and Clicks Retailers." European Management Journal 18(5): 542-55-.

Golder, P. N. and G. J. Tellis (1993). "Pioneer Advantage - Marketing Logic or Marketing Legend." Journal of Marketing Research 30(2): 158-170.

Griffith, D. A. and R. F. Krampf (1998). "An examination of web-based strategies of the Top 100 US retailers." Journal of Marketing Thoery \& Practice Summer 1998: 12-20. 
Griffith, D. A. and J. L. Palmer (1999). "Leveraging the Web for Corporate Success." Business Horizons Jan/Feb 1999: 3-10.

Gulati, R. and J. Garino (2000). "Get the right mix of bricks and clicks." Harvard Business Review 78(3): 107-114.

Hackbarth, G. and W. J. Kettinger (2000). "Building an E-Business Strategy." Information Systems Management(Summer 2000): 78-93.

Kerin, R. A., P. R. Varadarajan, et al. (1992). "1st-Mover Advantage - a Synthesis, Conceptual-Framework, and Research Propositions." Journal of Marketing 56(4): 33-52.

Kiang, M. Y., T. S. Raghu, et al. (2000). "Marketing on the Internet - who can benefit from an online marketing approach?" Decision Support Systems 27: 383-393.

Lindquist, J. D. (1975). "Meaning of Image." Journal of Retailing 50(4): 29-38.

Mellahi, K. and M. Johnson (2000). "Does it pay to be a first mover in e-commerce? The case of Amazon.com." Management Decision 38(7): 445-452.

Ng, H.-I., Y. J. Pan, et al. (1998). "Business Use of the World Wide Web: A report on further investigations." International Journal of Information Management 18(5): 291-314.

Peterson, R., S. Balasubramanian, et al. (1997). "Exploring the implications of the Internet for Consumer Marketing." Journal of Academy of Marketing Science 25(4): 329-346.

Phau, I. and S.-M. Poon (2000). "Factors influencing the type of product/services purchased over the Internet." Internet Research 10(2): 102-113.

Quinn, C. (1999). "How Leading edge E-commerce companies are marketing, selling and fulfilling over the Internet." Journal of Interactive Marketing 13(4): 39-50.

Reardon, J. and R. Hasty (1997). Retail Management, McGraw-Hill.

Savin, J. and D. Silberg (2000). "There's more to e-business than point and click." The Journal of Business Strategy 21(5): 11-13.

Schuette, D. (2000). "Turning E-Business barriers into strengths." Information Systems Management Fall 2000: 20-25.

Spiller, P. and G. L. Lohse (1997). "A Classification of Internet Retail Stores." International Journal of Electronic Commerce 2(2): 29-56.

Venkatraman, N. (2000). "Five steps to a Dot-Com strategy: how to find your footing on the Web." Sloan Management Review 41(3): 15-29.

Walsh, J. and S. Godfrey (2000). "The Internet: A new era in customer service." European Management Journal 18(1): 85-92. 